\title{
Earning opportunities and informal payment as influencing factors in medical students' speciality choice
}

\author{
András Mohos ${ }^{1 *}$, Thomas Frese ${ }^{2}$, László Kolozsvári ${ }^{3}$, József Rinfel ${ }^{4}$, Albert Varga ${ }^{1}$, Csenge Hargittay ${ }^{5}$, \\ Dalma Csatlós ${ }^{5}$ and Péter Torzsa ${ }^{5}$
}

\begin{abstract}
Background: The Hungarian primary care system faces a severe shortage of family physicians. Medical students' perceptions of family medicine need to be known and medical students need to be given appropriate and comprehensible information about this speciality. The expected future salary is an important factor in career choice. Most of the family doctors are self-employed and the practices have a corrected capitation-type financing. Although the majority of health care services are covered by social health insurance and are provided for the insured patients free of charge, informal payment is an existing phenomenon with different motivations and consequences. This study aimed to investigate medical students' knowledge about their future earning opportunities and their attitudes towards informal payment.

Methods: A cross sectional survey with a self-administered questionnaire was conducted. Each of the four Hungarian medical universities were represented by their medical students who attended family medicine lectures in person from December 2019 to April 2020. The students were asked about their career plans, about their estimations of current and ideal expected salaries and about the effect of expected income for the choice of specialisation. Their attitudes towards informal payment were assessed.

Results: Response rate was $67.3 \%(N=465 / 691)$. Almost two-thirds of the participants were women. Only $5 \%$ of the respondents ( $N=23 / 462)$ plan to work as a family doctor in the future. The vast majority (91.9\%) of the students had already thought about their future income. On a 10-point Likert scale (1 ='no influence', $10=$ 'very big influence') 76\% answered that the expected future income exerts a considerable ( $\geq 5$ Likert points) influence on their career choice in general. The mean of the ideal expected monthly income of the residents, GPs and other specialists was $€ 1154 \pm 648$, $€ 1696 \pm 904$ and $€ 2174 \pm 1594$, respectively. The mean of the monthly income for a GP, as estimated by the studenst, was $€ 1140$ in rural and $€ 1122$ in urban settings. More than four-fifths of the students $(N=375 / 453)$ rejected the practice of informal payment.
\end{abstract}

Conclusions: Expected salaray is one important aspect in the career choice of medical students, students wish to have more information on this topic. The reported ideal incomes are higher than those expected. This points to a relevant gap. However, most of the students do not accept informal payment as a possibility to close this gap. The

\footnotetext{
*Correspondence: mohosandris@gmail.com

${ }^{1}$ Faculty of Medicine, Department Family Medicine, University of Szeged,

6725 Tisza Lajos krt. 109, Szeged, Hungary

Full list of author information is available at the end of the article
} original author(s) and the source, provide a link to the Creative Commons licence, and indicate if changes were made. The images or other third party material in this article are included in the article's Creative Commons licence, unless indicated otherwise in a credit line to the material. If material is not included in the article's Creative Commons licence and your intended use is not permitted by statutory regulation or exceeds the permitted use, you will need to obtain permission directly from the copyright holder. To view a copy of this licence, visit http://creativecommons.org/licenses/by/4.0/. The Creative Commons Public Domain Dedication waiver (http://creativeco mmons.org/publicdomain/zero/1.0/) applies to the data made available in this article, unless otherwise stated in a credit line to the data. 
expected and the ideal income differ from the real incomes of Hungarian GPs - this indicates the need of bringing objectoive information to the students to enhance attractivity of GP as a carer choice.

Keywords: Career choice, Medical student, Income, Informal payment, Family physician, Hungary

\section{Background}

The healthcare system requires available, accessible, acceptable and well-qualified human resources. These are key factors in effective, high quality health services [1]. Hungary faces a considerable challenge in this sector, especially in primary care. The aging and the migration of active family physicians, paired with the growing number of vacant practices points to an increasingly burning problem [2].

For successful human resource recruitment in primary care, medical students' perceptions of family medicine and their motivations regarding career choice and specialisation need to be better understood [3]. Many factors could influence the choice of speciality. Some of them are unchangeable, for example gender, origin or family role model. On the other hand, other factors can be influenced, such as education or experiences. The expected salary or income (the two terms are used synonymously in the present paper) could also influence career plans and specialisation [4]. Career choice as a multifactorial process can be examined from many aspects and measured with many tools. In our research we asked students about these factors but in this article we focused only on the the impact of earning opportunities and informal payment on career choice [5].

When we examine the financial aspects of specialisation, we have to understand doctors' different earning opportunities. In this survey, we are focusing on the state healthcare system only and do not include the private sector. The doctors in Hungarian secondary care mostly work as civil servants. Their monthly salary varies from approximately $€ 470-1170$ depending on work hours and level of qualification [6]. Family doctors or family physicians (the two terms are used synonymously in the present paper) work in Hungarian primary care and only few of them are civil servants. They are mostly self-employed, have their own practices and a contract with the National Health Insurance Fund of Hungary. The practices have a corrected capitationtype financing and from this remuneration the family doctor is able to calculate their employees' and their own salary. Therefore, we cannot determine a unified salary for family physicians. Based on national financial data, we determined $€ 1000$ as the average monthly salary for a family physician in our study. In comparison to the data of Hungarian Central Statistical Office, the average monthly salary in Hungary, with the use of the central exchange rate, was $€ 739$ in April 2020 [7]. More important than the absolute value of the expected income is how it relates to the ideal expected income of students. The ideal expected income is understood as the income that provides an opportunity to ensure the adequate standard of living envisioned by the students and is suitable for expressing the social prestige of the medical profession. If we want to understand the real meaning of these incomes in an international context, we can use the concept of purchasing power parity (PPP). PPP is a macroeconomic metric to compare economic productivity and standards of living between countries through to buy the same amount of goods and services in each country. Hungary's PPP was 31.914 US Dollars, Germany's 52.386 US Dollars and the EU28's 43.188 in 2018 [8].

In Hungary, the majority of health care services are covered by social health insurance and are provided for the insured patients free of charge. Participation in the social health insurance system is compulsory. Employers pay a "social tax", whereas employees pay a social health insurance contribution. The contribution of some special groups (e.g. old age pensioners, minors and students) is covered by the government. The population of Hungary was almost completely covered (94.9\%) in 2017 [9, 10]. However, informal payment, called "gratitude payment" in Hungary, is an existing practice. Patients often give money to their caregivers. The motivation is not only the expression of gratitude, but they also try to secure "advantages" for themselves. On the other hand, as a legacy of socialist times when gratitude payment was seen as a tacitly accepted supplement to extremely low official incomes, many of the doctors still count on this money. It is a particular characteristic of the former Eastern Block states, but is also present in African, South-American and some Asian healthcare systems, and it is a current practice in Turkey and Greece. This method distorts the system, as it is contrary to principles of professional work and adversely influences doctor-patient relationships. The frequency of gratitude payment varies from specialisation to specialisation, but there is a significant group of doctors for whom this illegal income supplement plays an important role. Therefore, theoretically, they are against this practice but, in their daily routine, they are constrained to accept it because of financial reasons. Although many of the doctors and a considerable part 
of society are against the practice of informal payments, changes on systematic and social level are required to eliminate it $[11,12]$.

This study had two main objectives:

1. It aimed to investigate medical students' knowledge about their future earning opportunities in primary care and in secondary care. This, in turn, was compared with the estimated future salary and the expected ideal salary. We investigated the relationship between financial aspects and career choice, especially in terms of the specialty of family medicine.

2. We were interested in medical students' attitudes towards informal payment.

There were two hypotheses underlying this research: If family physicians were paid closer to the income perceived as ideal by students, the problem of a severe lack of young family physicians could be reduced. If the income of those working as physicians better matched their feelings of appropriateness and justice, the problem of informal payments would be reduced. The study did not test these hypotheses directly but adds relevant information to the topic by revealing what students think of how it should be. As this was a cross-sectional study, it was not appropriate to directly investigate causal relationships, but the results obtained may help to further investigate and discuss the topic on a scientific basis.

\section{Methods}

\section{Study design and participants}

In our cross-sectional survey we used a self-administered paper based questionnaire. Participation was voluntary and anonymous. Each of the four Hungarian medical universities (Budapest, Debrecen, Szeged, and Pécs) were represented by their fourth and fifth year medical students who attended face-to-face family medicine lectures at that time. At the end of the lectures, the students received a xeroxed copy of the questionnaire, filled it in and handed in before leaving. Because the four universities have different curricula and family medicine is included in different years, we had to involve the appropriate years everywhere. Data collection was carried out from December 2019 to April 2020. After this time, it had to be stopped due to the COVID-19 pandemic. After receiving appropriate information about the study, 465 students decided to participate in our study. Unfortunately, because of the Covid-19 Pandemic, we reached a lower response rate than we had initially expected. However, the nature of the limiting factor we can assume that the characteristic of the participant group of the students and the non-participant group of the students are not different. The gender ratio supports our assumption: it was $62.1 \%(288 / 464)$ in the participant group and 63.9\% $(379 / 593)$ in the non-participant group.

\section{Questionnaire}

We used a self-developed questionnaire. We collected sociodemographic data such as gender, age, place of origin, family role models (in terms of higher education attainment, medical degree or family physician in the family). Because of the heterogeneity of the definitions of rural and urban, we did not use strict categories in the categorisation of the settlements. The capital city is obviously Budapest, but when it came to the other categories (big city, small town, or rural area), the participants were free to decide their category. There were questions concerning future career plans: preferred speciality, institution and workplace. We assessed the effect of future income for the choice of specialisation: students' previous search for information about this topic, influence of possible salary on career choice, estimation of current and ideal salaries, and students' self-rated confidence regarding their estimations. We also asked students about their attitude towards informal payment. The scales and questions used to measure the impact of earning opportunities and informal payment have already been used in other studies in the international literature $[13,14]$. The intelligibility of the questionnaire was tested by a group of medical students who do their thesis at the Department of Family Medicine in Szeged.

\section{Data analysis}

We used IBM SPSS Statistics 24 Software for statistical analysis. Descriptive statistics were given in terms of counts and percentages, means and standard deviations (SD), respectively, complemented by medians and quartiles where appropriate. N's vary due to missing values. The data were analysed by univariate cross tabulation. The percentages were compared by $\chi^{2}$ statistics. The one-way analysis of variance (ANOVA) test was used to compare means and to determine whether there are any statistically significant differences between the independent groups. For further analysis of the categories the Scheffe post hoc test was administered. Statistical significance was considered as $p<0.05$ with a $95 \%$ level of confidence level (CI: 95\%).

\section{Results}

During the involved years 1057 medical students were studying at the four universities. Out of them 691 participated in mandatory or in elective (University of Szeged) family medicine lecture courses in the given period, who had the opportunity to participate in this research. Out of 691 students, who studied face-to-face family 
medicine from December 2019 to April 2020 in the Hungarian universities, 465 completed our questionnaire. The overall response rate was $67.3 \%(N=465 / 691)$. The response rate was $86.8 \%(n=145 / 167)$ in Debrecen, $23 \%$ $(n=38 / 165)$ in Pécs, 63\% $(n=131 / 208)$ in Budapest and $73.3 \%(n=151 / 206)$ in Szeged. Socio-demographic characteristics of the sample are presented in Table 1. Only $5 \%$ of the respondents $(N=23 / 462)$ plan to work as a family doctor in the future, $72 \%(N=333 / 462)$ of them have other speciality preferences and $23 \%(N=106 / 462)$ have not chosen their preferred speciality yet.

The vast majority of the students $(91.9 \% ; N=421 / 458)$ had already thought about their future income and $47.5 \%$ $(N=218 / 459)$ had inquired about the exact data. The information sources of the medical students are presented in Fig. 1.

On a 10-point Likert scale ( $1=$ 'no influence', $10=$ 'very big influence') $76 \%(N=347 / 457)$ answered that the expected future income has a considerable $(\geq 5)$ influence on their career choice (Fig. 2). More than half of the students $(N=238 / 447)$ would decide against a speciality with a lower expected salary.

Students indicated their income estimates in Hungarian forint. We used the 2020 April central rate $(1 \mathrm{EUR}=360$ HUF) to represent the data in Euros. The mean of the ideal resident, family physician and other specialist monthly income was reported to be $€ 1154 \pm 648$ (P25: 833; P75: 1389), €1696士904 (P25: 1111; P75: 1944) and $€ 2174 \pm 1594$ (P25: 1389; P75: 2500). More than
$85 \%$ of the respondents $(N=378 / 443)$ reported that the ideal income for a resident doctor should be between $€ 556-1389$ and $66.6 \%$ of the respondents $(N=291 / 437)$ said that the ideal income for a family physician should be between $€ 834-2222$. More than $95 \%$ of the respondents $(N=405 / 425)$ said that the ideal income for a nonfamily physician specialist doctor should be at least $€ 834$ (Fig. 3).

The means of the estimated incomes for resident doctors were between $€ 631-650$ depending on the location and chosen speciality. The mean of the estimated monthly income for a family physician was $€ 1140$ in rural and $€ 1122$ in urban settings; for other specialists $€ 1081$ and $€ 1166$, respectively. Students from the University of Debrecen estimated the highest income almost in all categories (except for urban specialists' income) (Table 2).

Only the minority of participants were "very certain" $(1.1-8.1 \%)$ or at least "rather certain" $(18-34.8 \%)$ in their estimations (Table 3).

Students reported that the ideal income of a non-family physician specialist should be significantly higher than that of a family doctor (Table 4).

More than four-fifths of the respondents $(N=375 / 453)$ theoretically reject informal payment (Fig. 4).

\section{Discussion}

In our study we found that expected salary plays an important role for medical students in their career choice. Most of them have already thought about it and

Table 1 Sample characteristics

\begin{tabular}{|c|c|c|}
\hline Variable & Valid $(\mathrm{N})$ & $\mathrm{N}(\%)$ \\
\hline Age $[$ mean $\pm S D]$ & 465 & $23.5+-2.1$ years \\
\hline Women & 464 & $288(62.1)$ \\
\hline At least one parent with higher education degree & 465 & $365(79.0)$ \\
\hline Being a physician's child & 465 & $85(18.3)$ \\
\hline Family or friends working in family medicine & 462 & $121(26.2)$ \\
\hline Family or friends working in the preferred speciality & 458 & $81(17.7)$ \\
\hline Comes from... & 457 & \\
\hline The capital city & & $85(18.6)$ \\
\hline A big city & & $160(35.0)$ \\
\hline A small town & & $141(30.8)$ \\
\hline A rural area & & $71(15.5)$ \\
\hline University of & 465 & \\
\hline Debrecen & & $145(31.2)$ \\
\hline Pécs & & $38(8.2)$ \\
\hline Budapest & & $131(28.2)$ \\
\hline Szeged & & $151(32.5)$ \\
\hline Year & 465 & \\
\hline Fourth & & $213(45.8)$ \\
\hline Fifth & & $252(54.2)$ \\
\hline
\end{tabular}



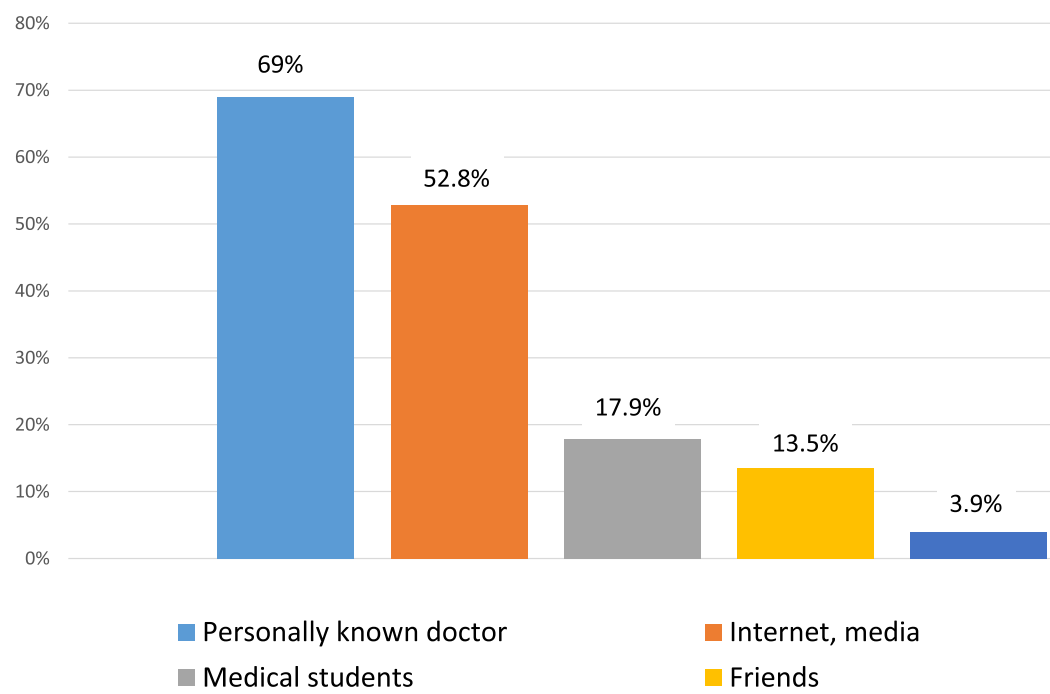

Fig. 1 Source of information about possible future income

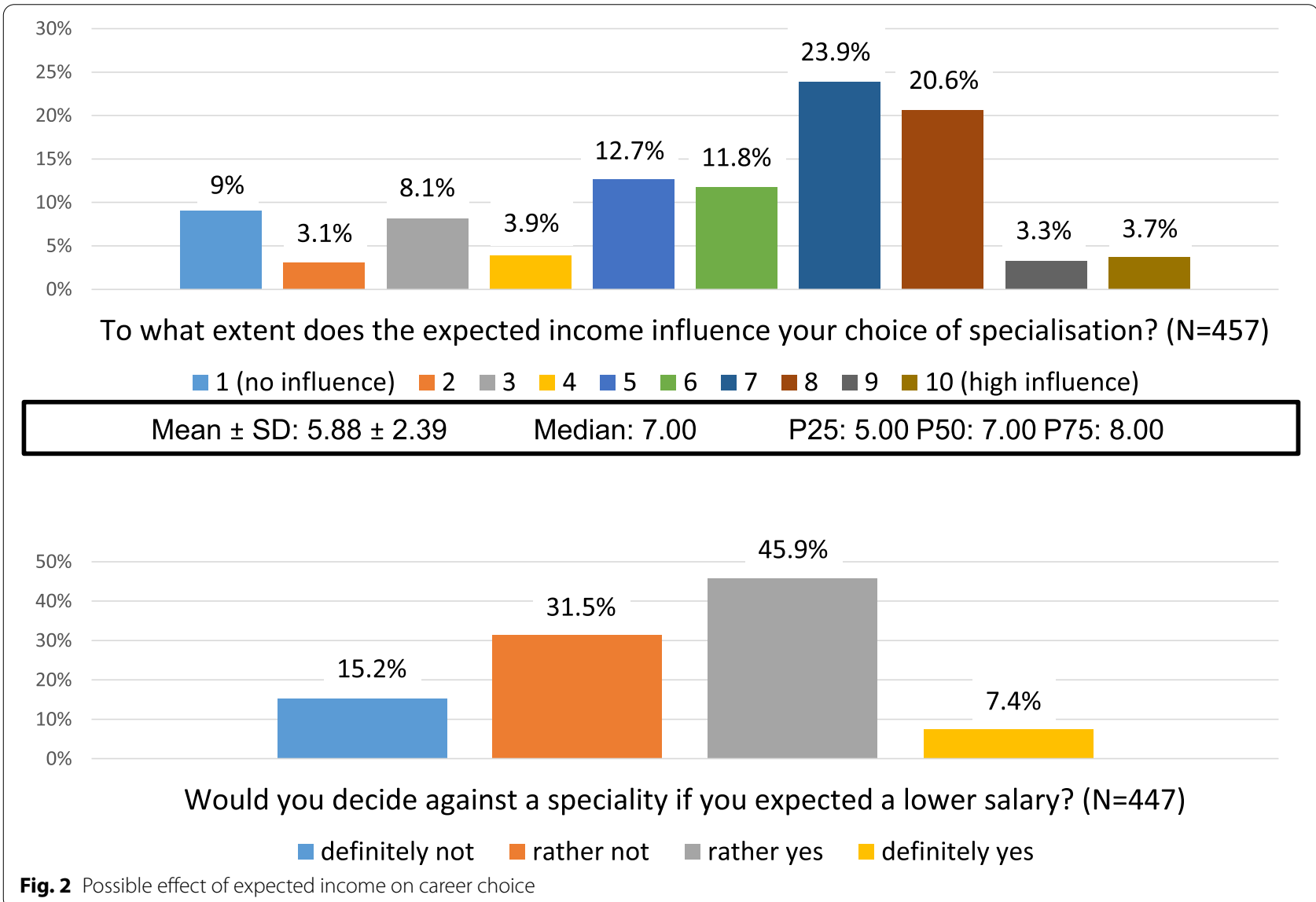

report that the expected salary could highly influence their choice of specialisation. On the other hand, only less than half of the students have exact information in
Internet, media

Friends

g. 2 Possible effect of expected income on career choice

this area. Students' information is mostly acquired from informal channels, such as doctors, other medical students or friends, and the media has a big impact as well. 


\section{Ideal income $(€)$}

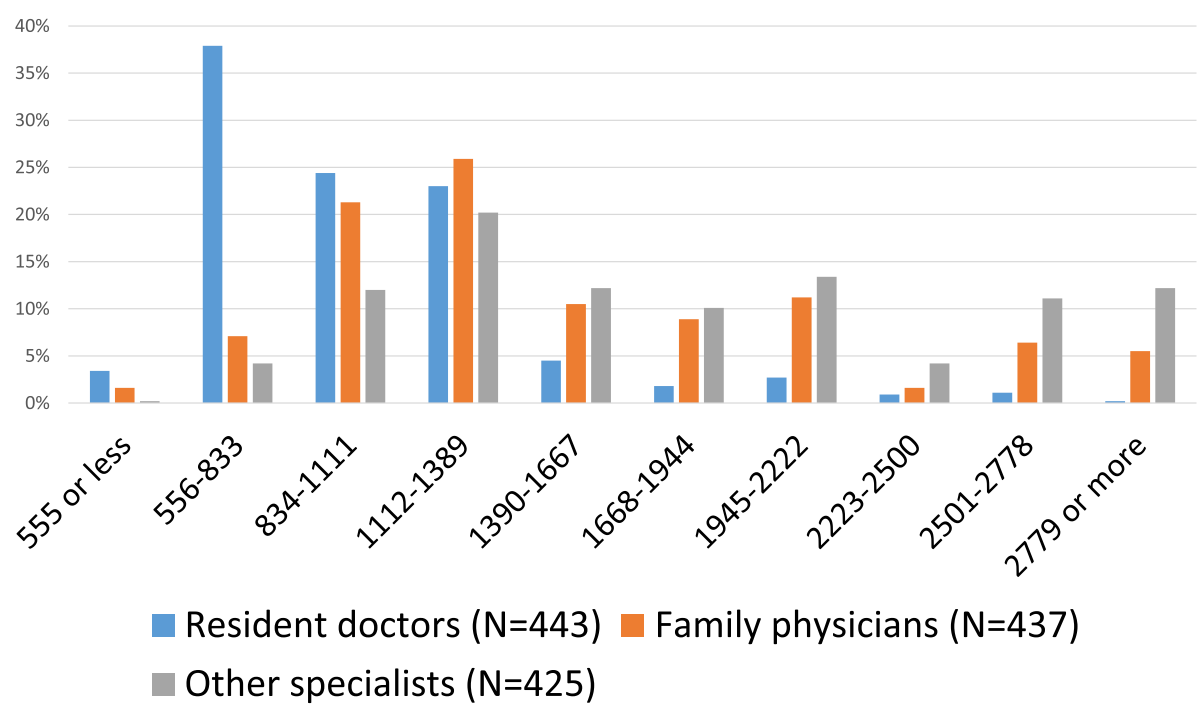

Fig. 3 Ideal monthly incomes according to the students

Table 2 Estimated incomes $(€)$

\begin{tabular}{llll}
\hline & Mean +- SD & P25 & P75 \\
\hline Rural FM residents & $639+-233$ & 486 & 778 \\
Urban FM residents & $631+-216$ & 500 & 694 \\
Rural family physicians & $1140+-790$ & 743 & 1389 \\
Urban family physicians & $1122+-532$ & 833 & 1389 \\
Other rural residents & $633+-241$ & 500 & 722 \\
Other urban residents & $650+-277$ & 500 & 743 \\
Other rural specialists & $1081+-432$ & 833 & 1250 \\
Other urban specialists & $1166+-539$ & 833 & 1389 \\
\hline
\end{tabular}

The university lectures provide an excellent opportunity for high quality professional training but do not create sufficient opportunities to get to know the working and living conditions associated with each speciality. Despite the information acquired through many different channels, or, rather due to that, most of the students are uncertain about the expected salaries. The importance of expected salary and uncertainty in the estimation in our study are in line with other international studies. In a recent German study, more than half of the students stated that earning opportunities are important in career choice and approximately $90 \%$ were uncertain in salary estimation. Naimer et al. in 2018 found that Israeli

Table 3 Certainty of salary estimates

\begin{tabular}{llll} 
Very uncertain (\%) & Rather uncertain (\%) & Rather certain (\%) & $\begin{array}{l}\text { Very } \\
\text { certain } \\
\text { (\%) }\end{array}$ \\
\hline 24 & 45 & 27.3 & 3.7 \\
21.8 & 38.1 & 34.8 & 5.3 \\
30.6 & 48.2 & 19 & 1.9 \\
30 & 46.6 & 20.9 & 2.4 \\
28.7 & 39.1 & 26.1 & 6.1 \\
26.6 & 36.3 & 29 & 8.1 \\
34.2 & 46.7 & 18 & 1.1 \\
33.4 & 44 & 20.4 & 2.2 \\
\hline
\end{tabular}

Rural FM residents $(N=429)$

Urban FM residents $(N=431)$

Rural family physicians $(N=415)$

Urban family physicians $(N=416)$

Other rural residents $(N=376)$

Other urban residents $(N=383)$

Other rural specialists $(N=366)$

Other urban specialists $(N=368)$

(1)


Table 4 The comparison of the estimated, ideal and real incomes $(€)$ (Mean + -SD)

\begin{tabular}{llll}
\hline & Estimated & Ideal & Real \\
\hline Rural FM residents & $639+-233$ & $1154+-648$ & 470 \\
Urban FM residents & $631+-216$ & $1154+-648$ & 470 \\
Rural family physicians & $1140+-790$ & $1696+-904$ & 1000 \\
Urban family physicians & $1122+-532$ & $1696+-904$ & 1000 \\
Other rural residents & $633+-241$ & $1154+-648$ & $470-490$ \\
Other urban residents & $650+-277$ & $1154+-648$ & $470-490$ \\
Other rural specialists & $1081+-432$ & $2174+-1594$ & $836-1170$ \\
Other urban specialists & $1166+-539$ & $2174+-1594$ & $836-1170$ \\
\hline
\end{tabular}

medical students do not have appropriate information about general practitioners' salaries either [13, 15].

In all three categories (resident, family physician and other specialist), the estimated salaries are close to reality; however, for residents, the estimated salary is higher than the actual one. The cause of this result could be that in Hungary there are many scholarships for residents and young doctors, which could mean an extra income of $€ 270-550$ above the official salary every month. Nevertheless, this result was surprising compared to our previous study where $84 \%$ of the students underestimated the expected salaries [16]. In another one of our previous studies, most family medicine residents also underestimated expected salaries [14]. Based on these findings, we can state that Hungarian medical students are becoming more and more informed about their future earning opportunities. German medical students also significantly underestimated earning opportunities [13]. We did not find significant differences between urban and rural estimated or ideal incomes. Ideal salaries significantly exceed the estimated ones in every category. The fact that the students reported that the ideal income of a nonfamily physician specialist should be significantly higher than that of a family doctor may be in line with the lower prestige of family medicine among medical students [17].

Every year, women are increasingly represented in medicine, so gender differences are important to address in human resources. Eith et al. (2006) found that in Hungary fifth year women medical students want to be engaged in their medical profession but family plans are at least as important to them [18]. In our study, gender seems to play an important role in salary estimation. Men estimated higher salaries in almost every category and they were more confident in their estimates. Our findings are in line with a study carried out among surgery residents where women expected lower starting and ideal salaries [19]. A previous study in Hungary stated that among first year medical students "lifestyle and income" is more important in speciality choice for men [20]. According to international surveys, these expectations are close to reality because male physicians usually have higher salaries than their female colleagues [21, 22]. Students from the University of Debrecen estimated the highest income in all categories. This correlation was a novel finding because we know that undergraduate education has a significant role in career choice but its effect on salary expectations is not yet well-known [23-25]. Preferred speciality and motivation to work in rural settings or abroad did not influence the estimations significantly.

Attitudes of doctors and medical students towards informal payment is a key question if we want to shed light on this phenomenon of the healthcare system. In our study, we found it to be somewhat controversial. In theory, more than eight out of ten students reject it. However, two thirds of the students will accept it if the system will not change, although with different motivations. What it means is that about half of the students are influenceable by rules or circumstances. In our previous study, we found that in 2014-2015 19.7\% of family physicians and $38.3 \%$ of family medicine residents were absolutely rejective of informal payment, 47 and $37.8 \%$ reported that their acceptance depends on the situation; mostly on the financial status of the patient [14]. Szinapszis Market Research and Consulting Ltd. regularly provides representative data about informal payment in Hungary. In their research in 2009 10\%, in 2013 19\%, in 2017 33\% were absolutely rejective of informal payment. In 2009 81\%, in $201378 \%$, in $201761 \%$ accepted it in their daily work depending on the circumstances [2628]. Based on these results we can see a positive tendency in doctors' attitudes, but it is not enough to stop this harmful practice. Patients' attitudes are at least as important. Baji et al. (2013) found that $47.3 \%$ of the respondents thought "Informal CASH payments to physicians and medical staff are similar to corruption." and 54\% answered that" Cash or gifts in kind, given informally to physicians and medical staff, should be eradicated." 51.7\% stated "If I have serious problems with my health, I will be ready to pay as much as I have in order to get better medical services." From these results it can be seen, that patients do not like informal payment; however, it is a very deeply rooted phenomenon in Hungarian society [11]. We found significant correlations between acceptance of informal payment and aspects in connection with the importance of income. This finding indirectly confirm our hypothesis that if physicians would have higher income the problem of informal payments would be solved. Gender is also an influencing factor; males more often accept informal payment. The reason for this difference is ambiguous, the role of the hidden curriculum and 


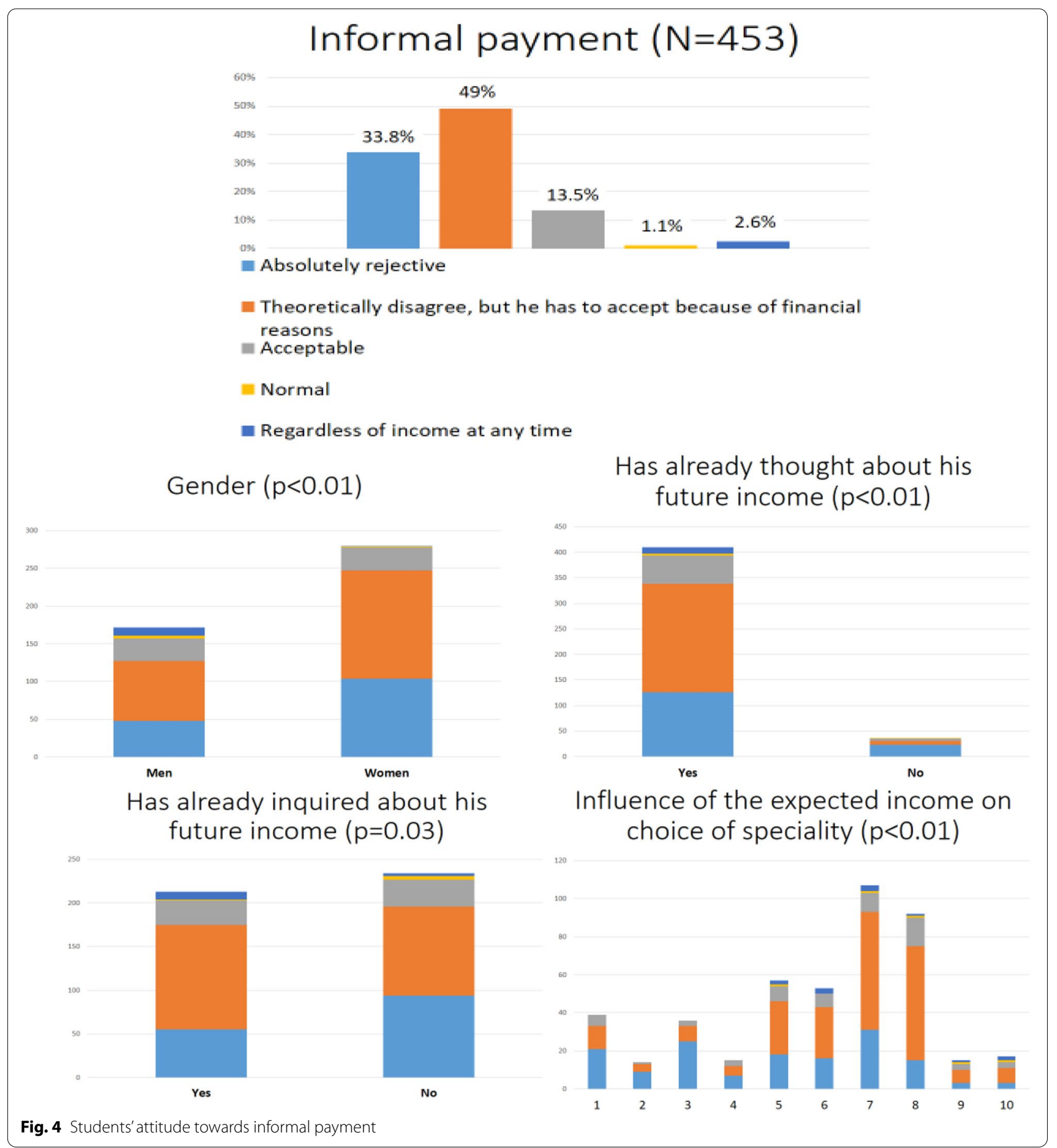

other factors outside education, like social gender roles, may be considered [29]. Human resource recruitment in the healthcare system and informal payment are not only medical questions but affect society as a whole. Therefore it is crucial to handle them a scientific basis without any political or emotional influence.

\section{Strengths and limitations}

This is the first study, which examined the effect of estimated future income on career choice among medical students at all of the four Hungarian medical universities. It provides current and relevant data in the topic of informal payment, which is a burning problem of the Hungarian healthcare system. The sample size and 
acceptable response rate allowed us to draw general conclusions. As a limitation, we have to mention that participants involved in our study included medical students from different stages of their medical education. Fourth and fifth year students may have different experiences and perceptions. The reason for this selection criteria was that we involved medical students, who were having family medicine lecture courses and the universities have different curricula. Due to the COVID-19 pandemic Hungarian universities transitioned to online education; therefore, we reached a lower response rate at the University of Pécs, which can limit the comparison of results from different universities. The cross-sectional study as study design is also a limiting factor. Cross-sectional data cannot be used to infer causality and we are not able to evaluate whether the perceptions and motivations persist in graduates. Only few of the medical students are interested in family medicine as a future specialty, so we could not describe the special characteristics of this group.

\section{Conclusions}

In our study the students state that earning opportunities have a big impact on career choice and specialisation. Medical students in Hungary made a good estimate of their future income; however, they were not confident and mostly obtained their information from unofficial sources. This uncertainty may influence their career choice and result in the rejection of an otherwise attractive speciality. Ideal incomes given by students are in all cases significantly higher than their estimated expected incomes. This is a sad, but realistic view at the moment, which also makes it difficult to ensure adequate human resource recruitment. Most students reject informal payment theoretically. This attitude may be used as an excellent opportunity to eradicate this harmful phenomenon but further action is needed to succeed.

Further studies should examine specialisation and detect other influencing factors and changes of students' perceptions and motivations with longitudinal examinations. A rise in medical salaries is essential to ensure the necessary amount of professionals in the healthcare system. Furthermore, providing accessible, accurate and clear information about earning opportunities is funamental. This is the common responsibility of the government, the media, medical organisations and medical education.

\section{Abbreviations}

ANOVA: Analysis of variance; Cl: Confidence level; $€$, EUR: Euro; FM: Family medicine; GP: General practitioner; HUF: Hungarian forint; PPP: Purchasing power parity; SD: Standard deviations.
Acknowledgements

Not applicable.

\section{Authors' contributions}

AM and TP contributed to conception and design, questionnaire development, data analysis, interpretation of the results and the first draft of the manuscript. TF critically revised the manuscript. LK, JR, AV, CsH and DCs contributed to data and literature collection and critically revised the manuscript. All authors read and approved the final version of the manuscript.

\section{Funding}

Open Access funding provided by Semmelweis University. There was no external funding for this study.

\section{Availability of data and materials}

The datasets used and/or analysed during the current study are available from the corresponding author on reasonable request.

\section{Declarations}

Ethics approval and consent to participate

Ethics approval was received from the Medical Research Council, Hungary, reference number 51983-2/2019/EKU.

Informed consent was obtained from all subjects.

All the experiment protocol for involving human data was in accordance with the Declaration of Helsinki in the manuscript.

\section{Consent for publication}

Not applicable.

\section{Competing interests}

The authors declare that they have no competing interests.

\section{Author details}

${ }^{1}$ Faculty of Medicine, Department Family Medicine, University of Szeged, 6725 Tisza Lajos krt. 109, Szeged, Hungary. ${ }^{2}$ Institute of General Practice and Family Medicine, Martin-Luther-University Halle-Wittenberg, Magdeburger Straße 8, 06112 Halle/Saale, Germany. ${ }^{3}$ Department of Family and Occupational Medicine, Faculty of Medicine, University of Debrecen, 4028 Kassai út 26, Debrecen, Hungary. ${ }^{4}$ Institute of Primary Care, University of Pécs, 7623 Rákoczi St. 2, Pécs, Hungary. ${ }^{5}$ Department of Family Medicine, Semmelweis University, 1085 Stáhly u. 9, Budapest, Hungary.

Received: 16 May 2021 Accepted: 7 September 2021

Published online: 30 December 2021

\section{References}

1. Campbell J, Dussault G, Buchan J, Pozo-Martin F, Guerra Arias M, Leone $C$, et al. A universal truth: no health without a workforce. Forum report, third global forum on human resources for health, Recife, Brazil. Geneva: Global Health Workforce Alliance and World Health Organization; 2013.

2. Cs B. The capacities of primary health care in Hungary: a problem statement. Eur J Investig Health Psychol Educ. 2020;10:327-45.

3. Barber S, Brettell R, Rafael Perera-Salazar R, Greenhalgh T, Harrington R. UK medical students' attitudes towards their future careers and general practice: a cross-sectional survey and qualitative analysis of an Oxford cohort. BMC Med Educ. 2018;18:160. https://doi.org/10.1186/s12909-018-1197-z.

4. Yang Y, Li J, Wu X, Wang J, Li W, Zhu Y, et al. Factors influencing subspecialty choice among medical students: a systematic review and meta-analysis. BMJ Open. 2019;9:e022097. https://doi.org/10.1136/bmjop en-2018-022097.

5. Lambert TW, Smith F, Goldacre MJ. Trends in attractiveness of general practice as a career: surveys of views of UK-trained doctors. Br J Gen Pract. 2017;67(657):e238-47. https://doi.org/10.3399/bjgp17X689893.

6. 256/2013. (VII. 5.) Korm. rendelet egyes egészségügyi dolgozók és egészségügyben dolgozók illetmény- vagy bérnövelésének, valamint az ahhoz kapcsolódó támogatás igénybevételének részletes szabályairól. (256/2013. (VII. 5.) Government Decree about certain healthcare workers' 
and workers' in healthcare salary or wage increases and related support detailed rules.) Available from: https://net.jogtar.hu/jogszabaly?docid= a1300256.kor. Accessed 24 Apr 2021.

7. Hungarian Central Statistical Office: Quick guide, earnings January 2020 April 2020. Available from: https://www.ksh.hu/docs/hun/xftp/gyor/ker/ ker2004.html. Accessed 24 Apr 2021.

8. Hungarian Central Statistical Office : 7.3.2. GDP per capita in purchasing power parity (2000 -). Available from: https://www.ksh.hu/docs/hun/ xstadat/xstadat_eves/i_int024b.html. Accessed 19 June 2021.

9. Gaál P, Szigeti S, Csere M, Gaskins M, Panteli D. Hungary health system review. Health Syst Transit. 2011;13(5):1-266.

10. Hungarian Central Statistical Office 2.8.3. Health interventions and services (2003-2017) Budapest: 2018. http://www.ksh.hu/thm/2/indi2_8_ 3.html. Accessed 24 Oct 2020.

11. Baji P, Pavlova M, Gulácsi L, Groot W. Exploring consumers' attitudes towards informal patient payments using the combined method of cluster and multinomial regression analysis - the case of Hungary. BMC Health Serv Res. 2013;13:62 Available from https://doi.org/10.1186/14726963-13-62. Accessed 24 Oct 2020.

12. Stepurko T, Pavlova M, Gryga I, Groot W. To pay or not to pay? A multicountry study on informal payments for health-care services and consumers' perceptions. Health Expect. 2015;180(6):2978-93. https://doi. org/10.1111/hex.12281.

13. Deutsch T, Heine A, Lippmann S, Geier AK, Bauer A, Frese T. Medical students' perspectives on earning opportunities of self-employed physicians - realistic and relevant for the process of career choice? BMC Med Educ. 2020;20:42. https://doi.org/10.1186/s12909-020-1950-y.

14. Torzsa P, Csatlós D, Eőry A, Hargittay C, Horváth F, László A, et al. Hivatással és hálapénzzel kapcsolatos vélekedések a magyarországi családorvosok és családorvos rezidensek körében. (Opinions of Hungarian family physicians and residents on vocation and informal payment.). Orv Hetil. 2016;157(36):1438-44.

15. Naimer S, Press Y, Weissman C, Zisk-Rony RY, Weiss YG, Tandeter H. Medical students' perceptions of a career in family medicine. Isr J Health Pol Res. 2018;7:1. https://doi.org/10.1186/s13584-017-0193-9.

16. Mohos A, Varga A, Markó-Kucsera M, Kalabay L, Torzsa P. A családorvoslás mint karrier. Orvostanhallgatók pályaválasztással kapcsolatos vélekedései és motivációi. (Family medicine as a career. Medical students'attitudes and vocational choice motivations.). LAM. 2019;29(12):627-34.

17. Lefebvre C, Hartman N, Tooze J, Manthey D. Determinants of medical specialty competitiveness. Postgrad Med J. 2020;96(1139):511-4. https:// doi.org/10.1136/postgradmedj-2019-137160.

18. Feith HJ, Kovácsné TÁ, Jövőkép BP. Az ötödéves orvostanhallgató-nők karrier- és családtervei. Future carrier and family plans of 5th-year female medical students. LAM. 2006;16(6):585-9.

19. Gray K, Neville A, Kaji AH, Wolfe M, Calhoun K, Farin Amersi F, et al. Career goals, salary expectations, and salary negotiation among male and female general surgery residents. JAMA Surg. 2019;154(11):1023-9.

20. Girasek E, Szócska M, Kovács E, Gaál P. The role of controllable lifestyle in the choice of specialisation among Hungarian medical doctors. BMC Med Educ. 2017;17:204. https://doi.org/10.1186/s12909-017-1031-z.

21. Ly DP, Seabury SA, Jena AB, Newhouse RL. Differences in incomes of physicians in the United States by race and sex: observational study. BMJ. 2016;353:i2923. https://doi.org/10.1136/bmj.i2923.

22. Jena $A B$, Olenski AR, Blumenthal DM. Sex differences in physician salary in U.S. public medical schools. JAMA. Intern Med. 2016;176(9):1294-304. https://doi.org/10.1001/jamainternmed.2016.3284.

23. Yoon JD, Ham SA, Reddy ST, Curlin FA. Role models' influence on specialty choice for residency training: a national longitudinal study. J Grad Med Educ. 2018;10(2):149-54. https://doi.org/10.4300/JGME-D-17-00063.1.

24. Howse K, Harris J, Dalgarno N. Canadian national guidelines and recommendations for integrating career advising into medical school curricula. Acad Med. 2017;92:1543-8. https://doi.org/10.1097/ACM.0000000000 001720

25. Alberti H, Randles HL, Harding A, McKinley RK. Exposure of undergraduates to authentic GP teaching and subsequent entry to GP training: a quantitative study of UK medical schools. Br I Gen Pract. 2017;67(657):e248-52. https://doi.org/10.3399/bjgp17X689881.

26. Szinapszis Kft. kutatási jelentés, 2009. Orvosaink a hálapénzről. (Physicians on informal payment) Available from http://www.szinapszis.hu/kutatasi_ eredmenyek/12/print. Accessed 24 Oct 2020
27. Szinapszis Kft. Kutatási jelentés, 2013. Hálapénz. Ki mennyit vár? (Informal payment. Who expects how much?). Available from https://index.hu/ belfold/2013/10/15/az_orvosok_is_utaljak_a_halapenzt/ Accessed 24 Oct 2020

28. Szinapszis Kft. Kutatási jelentés, 2017. [Internet] Végleg eltűnhet a hálapénz. (Informal payment may disappear permanently). Available from https://www.szinapszis.hu/hu/hirek/vegleg-eltnhet-a-halapenz. Accessed 24 Octob 2020

29. Mackin R, Baptiste S, Niec A, Kam J, AJ. The hidden curriculum: a good thing? Cureus. 2019;11(12):e6305. https://doi.org/10.7759/cureus.6305.

\section{Publisher's Note}

Springer Nature remains neutral with regard to jurisdictional claims in published maps and institutional affiliations.

Ready to submit your research? Choose BMC and benefit from:

- fast, convenient online submission

- thorough peer review by experienced researchers in your field

- rapid publication on acceptance

- support for research data, including large and complex data types

- gold Open Access which fosters wider collaboration and increased citations

- maximum visibility for your research: over $100 \mathrm{M}$ website views per year

At BMC, research is always in progress.

Learn more biomedcentral.com/submissions 